\title{
Causal Links between Foreign Direct Investment and Trade in Turkey
}

\author{
Burcu KIRAN \\ Faculty of Economics, Istanbul University, 34452, Beyazit, Istanbul, Turkey \\ E-mail: kburcu@istanbul.edu.tr
}

Received: August 8, 2010

Accepted: August 28, 2010

doi:10.5539/ijef.v3n2p150

\begin{abstract}
This paper investigates the empirical evidence on the link between foreign direct investment and trade (export and import) in Turkey over the period from 1992:01 to 2008:04 by using the minimum LM unit root test for stationarity; Granger and Dolado-Lüthkepohl tests for causality. The test results based on the bi-variate VAR model indicate that there is no evidence of causality between foreign direct investment and trade in Turkey.
\end{abstract}

Keywords: Foreign Direct Investment, Trade, Structural Breaks, Causality

\section{Introduction}

Foreign direct investment (FDI) is an important factor, especially for developing countries. It influences the production, employment, income, prices, exports, imports, economic growth, balance of payments and general welfare of the recipient country. It facilitates economic integration and growth through transfer of technologies and technological spillovers (Ponomareva, 2000). In other words, FDI inflows are expected to increase a country's output and productivity to encourage local investment and to stimulate the development and dispersion of technology (Sekkat and Varoudakis, 2004). Flows of FDI contributes to build strong economic links between industrialized and developing countries (Erdal and Tatoglu, 2002).

One major influence of FDI inflows is the trade effect, especially on the exports of a country. FDI stimulates exports by accumulating capital to foster export increase, helping transfer new technology and new products for exports, assisting access to new and profitable markets and accommodating training for domestic workforce and update technical, commercial and managerial skills (Temiz and Gökmen, 2009). On the other hand, FDI may have negative effects on an economy and exports as well. FDI inflows to a sector might replace domestic savings and create a crowding out effect on domestic investments, transfer old dated and inadequate technologies instead of enhancing factor opportunities. In these cases, inflows do not contribute to exportation and not provide assistance to improve host country's dynamic competitive advantages.

Another influence of FDI inflows can be on import of a country both at the initial investment and operation phases. At the initial investment phase, import of equipments, machineries, installation facilities and experts all contribute to increased import balance. In the operation phase of the investment, input nature, output type, productivity spill-over and type of relationship with other role players in the industry determine the direction of FDI on import. If FDI uses local raw materials and other inputs of production, it may not have significant adverse effect on import. On the contrary, if FDI uses imported inputs like raw material, human skills and other intangibles assets, it affects import positively (Hailu, 2010).

This paper investigates the causal relationship between FDI and trade (export and import) in Turkey over the period from 1992:01 to 2008:04. We use the minimum LM unit root test suggested by Lee and Strazicich (2003) which is a new method of unit root analysis with presence of structural breaks in univariate time series. The structural breaks are taken into account in the analysis of FDI and trade relationship because there have been significant changes in Turkey's external economic relations over the last decade. After considering the existence of structural breaks in the data, Granger causality and Dolado-Lüthkepohl (1996) causality tests are used in the study.

The remainder of this paper is structured as follows: Section 2 deals with literature review on the relationship between FDI and trade, Section 3 outlines the developments in FDI and trade in Turkey since 1980s. Section 4 describes the data, Section 5 presents econometric methodology and discusses the empirical results and Section 6 provides conclusion.

\section{Literature Review}

Although the theories have different origins and aims, the relationship between FDI and trade has recently been the subject of some studies in the literature. Trade theory tries to explain why countries trade with one another whereas FDI theory tries to explain why firms produce abroad and invest in particular countries (Mekki, 2005). There are mainly two aspects of possible linkages between FDI and trade: (a) whether FDI is a substitute for trade or a complement to trade; and (b) whether FDI causes trade or vice versa. 
According to trade theory, whether FDI substitutes or complements trade depends on the motivation for FDI. If FDI is vertical where multinational firms geographically split stages of production, this is likely to stimulate trade. If FDI is horizontal where multinational firms produce final goods in multiple locations, this is likely to substitute for trade. If FDI is a substitute for trade, then FDI represents a diversion away from local production and exports to foreign production and affiliate sales. Conversely, if FDI and trade complements, then the local production benefits from investments abroad (Taylor and Wilson, 2006).

In the neoclassical approach of trade theory, the paper of Robert Mundell (1957) is the first to focus on the relationship between capital movements and trade of commodities within the framework of the Heckscher-Ohlin-Samuelson (HOS) theory. The standard HOS theory of trade assumes homogeneous goods, constant returns to scale in production, identical, homothetic consumer preferences across countries and perfect competition in markets (Van Berkum, 2002). The HOS model suggests that international trade can substitute for international movement of factors of production including FDI and implies that international commodity trade involves an indirect exchange of factors between countries (Liu et al., 2001). Mundell (1957) argues that a tariff protection would generate a perfect substitution between FDI and trade. International trade and the international mobility of factors of production which includes FDI are substitutes rather than compliments for each other where there are barriers to trade. Trade impediments stimulate factor movements and that increased impediments to factor movements stimulate trade.

The opposing view is that FDI and trade are complements (Helpman, 1984; Helpman and Krugman, 1985). In this view, the difference in factor endowments plays an important role in determining the direction in which trade and FDI flow. Helpman(1984) and Helpman and Krugman (1985) argue that the degree of specialization is a positive function of relative factor endowments. If there are substantial differences in factor endowments, the capital-abundant country tends to export services into the labour-abundant country in exchange for finished varieties of a differentiated good or a homogeneous good (Favara, 2007). Thus, FDI generates complementary trade flows from the labour-rich country.

As we can understand from the theorical consideration, it is very difficult to predict whether FDI and trade substitutes or complements. Existing empirical studies in the literature which use different data and estimation techniques gives mixed results. Blomstrom et al. (1988) examines the relationship between FDI and exports by using the United States (US) and Swedish firm-level data and find complementary relationship between FDI and export. Eaton and Tamura(1994) analyse the American and Japanese bilateral flows of FDI and trade over the period 1985-1990 and find that the relationship between FDI and trade is complementary. Pfaffermary(1996) finds by using Austrian cross-sectional industry level data that there is a complementarity relationship between FDI and exports. Fontagne and Pajot (1997) investigates the relationship between FDI and trade for France, Sweden, US, the European Union (EU) and Japan over the period 1984 and 1994. They find that FDI and trade mostly act as complements. Dunning(1998) argues that the relationship between FDI and trade are conditional on the kind of FDI and trade. Gopinath et al. (1999) investigate the relationship between FDI and trade in the US food industry over the period 1982-1994 by using foreign affilate sales, exports, affilate employment and FDI as endogenous variables and conclude that foreign sales and exports are substitutes. Pontes (2004) finds for high level of trade costs that FDI and trade act as complements and otherwise as substitutes. Mekki (2005) finds that FDI and trade are complemetary for the manufacturing sectors of economy but are substitutes for other sectors in Tunusia.

The causal relationship between FDI and trade is as complex as substitution and complementary cases. Pfaffermary (1994) investigates the Granger causality relationship between Austrian outward FDI and exports and finds bi-directional causality among the variables. Jun and Singh (1996) find bi-directional causality between FDI inflows and exports for developing countries. Alguacil and Orts (2002) examine the impact of FDI on export in Spain by using quarterly data for the period 1970:Q1-1992:Q3 and find that there is a long-term Granger causality from FDI to exports. Alguacil et al. (2002) and Min (2001) investigate the relationship between FDI and export for Mexico and Malaysia, respectively, and find a positive causal relationship between FDI and exports. Liu et al. (2002) examine the relationship between growth, FDI inflows and trade for China and find bi-directional relationship between growth, FDI and exports but find only one way causality relationship to imports. Aizenman and Noy (2005) find bi-directional relationship between FDI flows and trade on the international level.

\section{Foreign Direct Investment and Trade in Turkey since 1980s}

The liberalization of foreign trade in Turkey started after the structural reforms in 1980. A new way opened in front of Turkey in terms of financial liberalization applications and structural adjustment programs. Import substitution policies have been abandoned and export-led growth strategy has been adopted. Price controls have been lifted, import regime gradually liberalized and FDI and export encouraging policies were followed (Hasanov and Omay, 2008). The foreign exchange regime was liberalized, banks were allowed to accept foreign currency deposit from citizens and to engage in foreign transactions and new market institutions were established. After the full 
liberalization of the capital account and the recognition of full convertibility of the Lira in 1989, there was a massive inflow of short term capital into the economy (Balkan and Yeldan, 2001).

The cumulative of FDI until 1980 was only \$ 228 million. Since the mid-1980s, foreign investors have been taking increasingly prominent role in the Turkish economy as the recent liberal foreign investment and privatization policies began to show their results (Erdal and Tatoğlu, 2002). The distribution of cumulative authorized FDI by country of origin can be seen in Table 1.

[Insert Table 1 here]

The table reports that European countries take the lead by accounting for over two-third of the total value of FDI. Following the European countries are the USA and Far Eastern countries with having shares of $12.0 \%$ and $6.4 \%$, respectively. According to the report of August 1999, manufacturing sector accounts for 56.7 per cent of cumulative FDI authorizations with services constituting nearly 41 per cent. Agriculture and mining, however, take very small portion of FDI with both sectors together constituting 2.51 per cent of cumulative FDI authorizations.

The integration process of the Turkish economy into the world economy gained further momentum following the Custom Union with the EU in 1996. Nearly 12 years after the Customs Union, EU has a stable share of around 50\% in Turkey's foreign trade. The Custom Union is important for Turkey's production structure, since $85 \%$ of total imports are intermediary and investment goods. The biggest increase in imports from the EU is in consumer products. The share of consumer goods rose to $15.1 \%$ in 2007 from $7.3 \%$ in 1994, while the share of investment goods decreased to $21.4 \%$ from $29.3 \%$. On the other hand, the share of investment goods in total exports from Turkey to the EU rose to $14 \%$ in 2007 from $2.9 \%$ in 1994, and the share of intermediate goods rose from $32.5 \%$ to $38.7 \%$, while the share of consumer goods declined to $47.1 \%$ from $64.6 \%$ in the same period (İzmen and Yilmaz, 2009). However, liberalization brought important structural problems and deep crises to the Turkish economy. Integration into the European Customs Union affected the Turkish trade balance predominantly until as recently as 2006. The 1997 Asian financial crisis and the subsequent Russian crisis in 1998 affected the Turkish trade balance in a negative way because the export volume could not be increased while the import volume maintained a growing trend. And as the anti-inflationary stabilization program based on nominal exchange anchor appreciated the domestic currency, it also deteriorated the trade balance. The stabilization program was unsuccessful in attaining the ex-ante crawling-peg regime leading to the February 2001 Turkish economic crisis. This crisis resulted in a massive depreciation of domestic currency against hard currencies such as the US Dollar and Euro. These developments brought about a narrowing effect upon imports, and supported the exports in a positive way. However, having a stabilized economy and having attained a sustainable growth path, trade balance again began depreciating until 2006, although massive increases in exports can be provided by policymakers. Table 2 reports the foreign trade indicators over the period 1980-2008.

[Insert Table 2 here]

As can be seen from the table, there is a prevaling reality that the import volume is more than export volume. Therefore, Turkey has been subject to a negative trade balance, balance of payment difficulties and necessary capital accumulation.

The FDI performance of Turkey has significantly improved since 2005. Turkey was ranked the fifth among the emerging markets in terms of attracting FDI inflows in 2006. Total FDI inflows added up to US\$ 52 billion during 2005-2006 while the total FDI stock reached US\$ 115 billion at the end of 2007 (İzmen and Y1lmaz, 2009). Despite the fact that, the amount of FDI inflow increases in Turkey, the state is subject to substantial amount of negative trade balance, current account deficit and budget deficit. Therefore, it is essential to facilitate more FDI inflow to solve economic problems of Turkey.

\section{Data}

To investigate the relationship between foreign direct investment and trade in Turkey, we use the ratio of foreign direct investment to GDP (FDI/GDP), the ratio of export to GDP (EX/GDP) and the ratio of import to GDP (IM/GDP). The quarterly data over the 1992:01- 2008:04 period are obtained from the IMF's International Financial Statistics database. All the variables are measured in Million dollars.

\section{Methodology and Empirical Results}

This section analyses the empirical relationship between foreign direct investment and trade in Turkey. On one hand, we investigate the relationship between FDI/GDP and EX/GDP. On the other hand, we investigate the relationship between FDI/GDP and IM/GDP. As a first step of our empirical analysis, we test for the order of integration of the series by using Augmented Dickey Fuller (ADF) and Philips Perron (PP) unit root tests. The test results are reported in Table 3.

[Insert Table 3 here] 
The results for the order of integration of the variables do not seem to be clear cut. The variables are found stationary after first differencing according to ADF test but found stationary in levels according to PP test. These findings show that the variables are inconclusive either $I(0)$ or $I(1)$ depending on the specific unit root test procedures. Perron (1989) argues that the presence of structural change in ADF test can reduce the power of the test and that the changes in the deterministic components of the time series can lead to biased results. Therefore, in order to capture the effect of any possible structural breaks, we also use the minimum LM unit root test suggested by Lee and Strazicich (2003). This test is not affected by the breaks in examining the stationarity properties and allows for two endogenously determined breaks in the intercept and trend.

\subsection{Minimum LM unit root test with two structural breaks}

The data-generating process (DGP) for the minimum LM unit root test suggested by Lee and Strazicich (2003) with two structural breaks is expressed by:

$$
y_{t}=\delta Z_{t}+e_{t}, \quad e_{t}=\beta e_{t-1}+\varepsilon_{t}
$$

where $Z_{t}$ consists of deterministic terms and $\varepsilon_{t} \sim$ iid $N\left(0, \sigma^{2}\right)$. The LM unit root test with two structural breaks can be considered as follows. Model AA allows two structural breaks in the intercept, and is described by $Z_{t}=\left[1, t, D_{1 t}, D_{2 t}\right]$ where

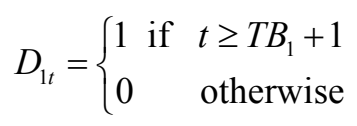

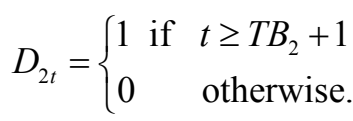

Here, $\mathrm{TB}_{1}$ and $\mathrm{TB}_{2}$ denote the break dates. Model $\mathrm{CC}$ includes two breaks in the intercept and the trend, and is described by $Z_{t}=\left[1, t, D_{1 t}, D_{2 t}, T_{1 t}, T_{2 t}\right]$ where

$$
\begin{aligned}
& T_{1 t}= \begin{cases}t-T B_{1} \text { if } & t \geq T B_{1}+1 \\
0 & \text { otherwise }\end{cases}
\end{aligned}
$$

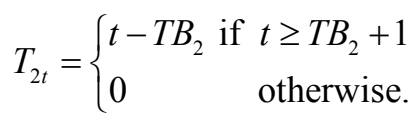

The LM unit root test statistic is obtained from the following regression:

$$
\Delta y_{t}=\alpha^{\prime} \Delta Z_{t}+\phi \tilde{S}_{t-1}+\sum \gamma_{i} \Delta \tilde{S}_{t-i}+\mu_{t}
$$

where $\tilde{S}_{t}$ is a detrended series such that $\tilde{S}_{t}=y_{t}-\tilde{\psi}_{x}-Z_{t} \tilde{\delta}_{t}, t=2, . ., T . \tilde{\delta}$ is a vector of coefficients in the regression of $\Delta y_{t}$ on $\Delta Z_{t} ; \quad \tilde{\psi}_{x}=y_{1}-Z_{1} \tilde{\delta}$ and $y_{1}$ and $Z_{1}$ are the first observations of $Y_{t}$ and $Z_{t}$, respectively. $\Delta$ is the difference operator. The lagged terms $\Delta \tilde{S}_{t-i}, i=1, . ., k$, are inserted to correct for serial correlation in equation 2 . The number of augmentation terms $\Delta \tilde{S}_{t-i}, i=1, . ., k$, is determined by following a "general to specific" procedure (starting with $\max k=4$ for quarterly data) described in Strazicich et al. (2004). The unit root hypothesis is tested via the $t$-ratio of $\phi$, this statistic being denoted as $\tilde{\tau}$. The null hypothesis of a unit root is tested against the alternative hypothesis of trend stationarity. Structural break $(T B)$ is determined by selecting all possible break points for the minimum $t$-statistic as follows:

$$
L M_{\tau}=\inf _{\lambda} \tilde{\tau}(\lambda)
$$

where $\lambda=T_{B} / T$. The critical values are tabulated in Lee and Strazicich (2003) for the two breaks case.

The results of the minimum LM unit root test with two structural breaks can be seen in Table 4 .

[Insert Table 4 here]

Based on the minimum LM unit root test results, we find that all the series are stationary in levels. Estimated break points are shown in Table 4 under columns $T B_{1}$ and $T B_{2}$. The second break in the intercept $\left(D_{2 t}\right)$ and the first break in the trend $\left(T_{1 t}\right)$ are significant for the $F D I / G D P$ ratio. The two breaks in the intercept $\left(D_{1 t}, D_{2 t}\right)$ and the 
trend $\left(T_{1 t}, T_{2 t}\right)$ are significant for the ratio of $I M / G D P$. For the $E X / G D P$ ratio, we find that the first break in the intercept $\left(D_{1 t}\right)$ and the two breaks in the trend $\left(T_{1 t}, T_{2 t}\right)$ are significant. The breaks for $F D I / G D P$ occur at 2005:01 and 2007:01. As explained in the Section 3, FDI performance of Turkey has significantly improved since 2005 and total FDI stock reached US\$ 115 billion at the end of 2007. According to the results for EX/GDP ratio, the break points coincide at 1997:03 and 2001:02. These breaks can be attributed to the effects of Asian financial crisis and February 2001 Turkish economic crisis. The breaks for the ratio of IM/GDP occur at 1996:02 and 1998:03, the years of European Customs Union and Russian crisis, respectively.

\subsection{Granger Causality Test}

Engel and Granger (1987) and Yoo (2005) point out that if there is no evidence for cointegration among the variables, the specification of the Granger causality test will be a Vector Autoregression (VAR). If evidence for cointegration is found, then one needs to augment the Granger type causality test with a one period lagged error correction term. In a bi-variate case, we can represent the two variable VAR system by the following equations:

$$
\begin{aligned}
& y_{1 t}=\alpha_{0}+\sum_{i=1}^{k} \alpha_{1 i} y_{1 t-i}+\sum_{i=1}^{k} \alpha_{2 i} y_{2 t-i}+\varepsilon_{1 t} \\
& y_{2 t}=\beta_{0}+\sum_{i=1}^{k} \beta_{1 i} y_{1 t-i}+\sum_{i=1}^{k} \beta_{2 i} y_{2 t-i}+\varepsilon_{2 t}
\end{aligned}
$$

where $y_{1 t}$ and $y_{2 t}$ denote the two stationary time series and $\varepsilon_{1 t}$ and $\varepsilon_{2 t}$ are assumed to be serially uncorrelated with zero mean and finite covariance matrix. $\mathrm{k}$ is the maximum lag order. When the null hypothesis $H_{0}: \alpha_{21}=\alpha_{22}=\cdots=\alpha_{2 k}=0$ is true, it suggests that $y_{2 t}$ does not Granger cause $y_{1 t}$. If the null hypothesis $H_{0}: \beta_{11}=\beta_{12}=\cdots=\beta_{1 k}=0$ is not rejected, it implies that $y_{1 t}$ does not Granger cause $y_{2 t}$.

Given that the series are stationary in levels, it will be infeasible to consider a cointegration analysis between the variables. Therefore, the natural course is to estimate the VAR model in our analysis. Since the ratio of FDI/GDP has two breakpoints in 2005:01 and 2007:01, the ratio of EX/GDP has two breakpoints in 1997:03 and 2001:02, and the ratio of $I M / G D P$ has two break points in 1996:02 and 1998:03, we need to take into account the estimated breakpoints and detrend the series through the following regression,

$$
y_{t}=\mu_{t}+\theta_{1} D_{1 t}+\theta_{2} D_{2 t}+\beta t+\gamma_{1} T_{1 t}+\gamma_{2} T_{2 t}+\tilde{y}_{t}
$$

where $\tilde{y}_{t}$ is detrended stationary series (Altnay and Karagol, 2004). By using detrended series, the VAR model is specifically constructed to examine the Granger causality relationship between FDI/GDP and EX/GDP and between FDI/GDP and IM/GDP. The lag structure of the VAR model for FDI/GDP and EX/GDP relationship is chosen by the Akaike Information Criterion (AIC), Schwartz Information Criteria (SC), LR test statistic, Final Prediction Error (FPE) and Hannan-Quinn Information Criterion (HQ), setting the maximum lag at 1 . The optimal lag length of the VAR model for FDI/GDP and IM/GDP relationship is chosen by using the AIC, LR and FPE criteria, setting the maximum lag at four. The results of the Granger causality test are shown in Table 5.

[Insert Table 5 here]

The test statistics show that there is no evidence of Granger causality between FDI/GDP and EX/GDP and between FDI/GDP and IM/GDP. To test causality relationship among the variables, we also use Modified Wald (MWALD) test developed by Dolado and Lüthkepohl (1996). This test procedure is a simple and intuitive method that overcomes the difficulties associated with standard Granger causality test that variables may or may not be integrated-cointegrated.

\subsection{MWALD Approach to Causality}

The Dolado and Lüthkepohl (1996) causality test uses the Augmented VAR model and does not require pretesting for cointegration properties. The Dolado-Lüthkepohl test can be directly applied to the series in levels, regardless of whether the series are integrated, stationary or stationary around a trend. To apply this test, the first step is to select the number of optimal lags for the variables in the VAR systems. In the second step of the causality analysis, we estimate VAR models with $(\mathrm{k}+1)$ lags and apply standard Wald test to the first $\mathrm{k}$ VAR coefficient. The Wald statistic will be asymtotically distributed as a chi-square, with degrees of freedom equal to the number of "zero restrictions" irrespective of whether the variables are $I(0), I(1)$ or $I(2)$, non-cointegrated or cointegrated of an arbitrary order. By using the FDI/GDP, EX/GDP and IM/GDP series in levels, we find the optimal lag length as 4 for both FDI/GDP -EX/GDP and FDI/GDP - IM/GDP relationships according to AIC, SC, LR, FPE and HQ criterations. Following Dolado and Lüthkepohl (1996), we estimate VAR model by adding only one extra lag to the 
true lag order $(4+1=5)$ and perform a Wald test on the coefficient of the first 4 lags. Table 6 gives the results from the Dolado and Lüthkepohl (1996) causality test.

[Insert Table 6 here]

As can be appreciated from the table, there is no evidence of a causal relationship between FDI/GDP - EX/GDP and FDI/GDP - IM/GDP. These results show that there is no causal relationship between foreign direct investment and trade in Turkey. As reported before, despite the fact that, the amount of FDI inflow increases in Turkey, the state is subject to some economic problems and in order to solve these problems, it is essential to facilitate more FDI inflow. Thus, Turkish economy should motive to improve some conditions, such as educated labor, developed financial system and political instability, before having foreign investment.

\section{Conclusion}

This paper examines the causal relationship between FDI and trade in Turkey by using quarterly time series data for the period 1992:01 to 2008:04. The ADF and PP unit root tests are performed to determine whether the series are stationary in levels or require first differencing. The findings show that these unit root test procedures give inconclusive results. The series are found stationary after first differencing according to ADF test but found stationary in levels according to PP test. Following Perron(1989), we take into account possible structural breaks in the data to avoid from the biased results. The minimum LM unit root test of Lee and Strazicich (2003) which allows for two endogenously determined breaks in the intercept and trend is used in the analysis. The findings indicate that the series are stationary in the levels with two structural breaks. To test causality relationship among the variables, Granger causality and Dolado and Lüthkepohl (1996) causality tests based on VAR models are applied. These test results imply that there is no causal relationship between FDI and trade in Turkey. According to these results, it can be said that Turkish economy should motive to improve some conditions, such as educated labor, developed financial system and political instability, before having foreign investment.

\section{References}

Aizenman, J., \& Noy, I. (2005). FDI and Trade - Two-way Linkages?. Working Paper. 11403, National Bureau of Economic Research (NBER).

Alguacil, M., Cuadros, A., \& Orts, V. (2002). Foreign Direct Investment, Exports and Domestic Performance in Mexico: A Causality Analysis. Economics Letters. 77, 371-376, doi:10.1016/S0165-1765(02)00150-7, http://dx.doi.org/10.1016/S0165-1765(02)00150-7

Alguacil, M.T. \& Orts, V. (2002). A Multivariate Cointegrated Model Testing for Temporal Causality between Exports and Outward Foreign Investment: The Spanish Case. Applied Economics. 34, 119-132, doi:10.1080/00036840110046818, http://dx.doi.org/10.1080/00036840110046818

Altınay G., \& Karagöl E. (2004). Structural Break, Unit Root, and the Causality Between Energy Consumption and GDP in Turkey. Energy Economics. 26, 985-994, doi:10.1016/j.eneco.2004.07.001, http://dx.doi.org/10.1016/j.eneco.2004.07.001

Balkan, E., \& Yeldan. E. (2001). Peripheral Development Under Financial Liberalization: The Turkish Experience. [Online] Available: http://academics.hamilton.edu/economics/home/Workpap/01_01.pdf

Blomstrom, M., Lipsey, R.E., \& Kulchycky, K. (1988). US and Swedish Direct Investment and Exports. In: R.E. Baldwin (Ed), Trade Policy Issues and Empirical Analysis. 259-297, Chicago: University of Chicago Press.

Dolado, J.J., \& Lütkepohl, H. (1996). Making Wald Tests Work for Cointegrated VAR Systems. Econometric Reviews. 15, 369-386, doi:10.1080/07474939608800362, http://dx.doi.org/10.1080/07474939608800362

Dunning, J.H. (1998). The European Internal Market Program and Inbound Foreign Direct Investment, In: J.H. Dunning (Ed), Globalization, Trade and Foreign Direct Investment. 49-115, Oxford: Elsevier, doi:10.1111/1468-5965.00048, http://dx.doi.org/10.1111/1468-5965.00048

Eaton, J., \& Tamura, A. (1994). Bilateralism and Regionalism in Japanese and US Trade and Direct Foreign Investment Patterns. Journal of Japanese and International Economics. 8, 478-510, doi:10.1006/jjie.1994.1025, http://dx.doi.org/10.1006/jjie.1994.1025

Engel, R., \& Granger, C. (1987). Cointegration and Error Correction: Representation, Estimation and Testing. Econometrica.55, 257-276, ISSN: 00129682

Erdal, F., \& Tatoglu, E. (2002). Locational Determinants of Foreign Direct Investment in an Emerging Market Economy: Evidence from Turkey. Multinational Business Review. 10, 21-27, ISSN: 1525383X

Favara, M. (2007). FDI and Trade in Eight MENA Countries: Complements or Subtitutes? A Gravity Model Analysis. Working Paper. 3, Department of Economic and Financial Sciences, University of Genoa. 
Fontagne, L., \& Pajot, M. (1997). How Foreign Direct Investment Affects International Trade and Competitiveness: An Empirical Assessment. Working Paper. 17, CEPII Research Center.

Gopinath, M., Pick, D., \& Vasavada, U. (1999). The Economics of Foreign Direct Investment and Trade with An Application to the US Food Processing Industry. American Journal of Agricultural Economics. 81, 442-452, http://www.jstor.org/stable/1244593

Hailu, Z.A. (2010). Impact of Foreign Direct Investment on Trade of African Countries. International Journal of Economics and Finance. 2, 122-133, ISSN:1916-9728

Hasanov, M., \& Omay. T. (2008). Monetary Policy Rules in Practise: Re-examining the Case of Turkey. Physica A. 387, 4309-4318, doi:10.1016/j.physa.2008.02.075, http://dx.doi.org/10.1016/j.physa.2008.02.075

Helpman, E. (1984). A Simple Theory of International Trade With Multinational Corporations. Journal of Political Economy. 92, 451-471, http://www.jstor.org/stable/1837227

Helpman, E., \& Krugman, P.R. (1985). Market Structure and Foreign Trade. MIT Press, Cambridge.

İzmen, Ü., \& Yılmaz, K. (2009). Turkey's Recent Trade and Foreign Direct Investment Performance. Tüsiad-Koç University Economic Research Forum, Working Paper. 0902, 1-30.

Jun, K.W., \& Singh, H. (1996). The Determinants of Foreign Direct Investment in Developing Countries. UNCTAD: Transnational Corporations. 5, 67-105, ISSN: 1014-9562

Lee, J., \& Strazicich , M.C. (2003). Minimum Lagrange Multiplier Unit Root Test with Two Structural Breaks. Review of Economics and Statistics. 85, 1082 - 1089, doi:10.1162/003465303772815961, http://dx.doi.org/10.1162/003465303772815961

Liu, X., Burridge, P., \& Sinclair, P. J. N. (2002). Relationships between Economic Growth, Foreign Direct Investment and Trade: Evidence from China. Applied Economics. 34, 1433-1440, doi:10.1080/00036840110100835, http://dx.doi.org/10.1080/00036840110100835

Liu, X., Wang, C., \& Wei, Y. (2001). Causal Links Between Foreign Direct Investment and Trade in China. China Economic Review. 12, 190-202, doi:10.1016/S1043-951X(01)00050-5, http://dx.doi.org/10.1016/S1043-951X(01)00050-5

Mekki, R. (2005). The Impact of Foreign Direct Investment on Trade: Evidence from Tunisia. 4th Annual Conference of the European Economics and Finance Society on 'Economic and Financial Issues in an Enlarged Europe, Coimbra, Portugal.

Min, S.B. (2001). FDI and Trade. Journal of Asia Pasific Economy. 8, 229-250, doi:10.1080/1354786032000074749, http://dx.doi.org/10.1080/1354786032000074749

Mundell, R.A. (1957). International Trade and Factor Mobility. The American Economic Review. 47, 321-335, http://www.jstor.org/stable/1811242

Perron, P. (1989). The Great Crash, The Oil Price Shock, and The Unit Root Hypothesis. Econometrica. 57, 1361-1401, http://www.jstor.org/stable/1913712

Pfaffermary, M. (1994). Foreign Direct Investment and Exports: A Time Series Approach. Applied Economics. 26, 337-351, doi: 10.1080/00036849400000080, http://dx.doi.org/10.1080/00036849400000080

Pfaffermary, M. (1996). Foreign Outward Direct Investment and Exports in Austrian Manufacturing: Substitutes or Complements. Weltwirtschaftliches Archiv. 132, 501-552, doi:10.1007/BF02707510, http://dx.doi.org/10.1007/BF02707510

Ponomareva, N. (2000). Foreign Direct Investment in Russia: Effects on Productivity. Paper presented at the EERC Annual Conference.

Pontes, J. P. (2004). A Theory of the Relationship between Foreign Direct Investment and Trade. Economics Bulletin. $6,1-8$.

Sekkat, K., \& Varoudakis, M.A. (2004). Trade and Foreign Exchange Liberalization, Investment Climate and FDI in the MENA Countries. Finance, Economy and Risk Network, Working Paper. [Online] Available: http://ideas.repec.org/p/sol/wpaper/04-023.html.

Strazicich, M.C., Lee, J., \& Day, E. (2004). Are Incomes Converging Among OECD Countries? Time Series Evidence With Two Structural Breaks. Journal of Macroeconomics. 26, 131-145, doi:10.1016/j.jmacro.2002.11.001, http://dx.doi.org/10.1016/j.jmacro.2002.11.001

Taylor, A.M., \& Wilson, J.L.F. (2006). International Trade and Finance under the Two Hegemons: Complementaries in the United Kingdom 1870-1913 and the United States 1920-30. NBER Working Papers. 12543, National Bureau of Economic Research. 
Temiz, D., \& Gökmen, A. (2009). Foreign Direct Investment and Export in Turkey: The Period of 1991-2008. Paper presented at the Anadolu International Conference in Economics.

Van Berkum, S. (2002). Trade and Foreign Direct Investment Patterns: The Case of Dutch Agribusiness. Academic Thesis. Amsterdam: University of Amsterdam.

Yoo, S. (2005). Electricity Consumption and Economic Growth: Evidence from Korea. Energy Policy. 33, 1627-1632, doi:10.1016/j.enpol.2004.02.002, http://dx.doi.org/10.1016/j.enpol.2004.02.002

Table 1. Distribution of Cumulative Authorized FDI by Country of Origin as of August 1999 (\$ US Millions)

\begin{tabular}{|lcc|}
\hline Country & Total & \% \\
\hline European Countries & $\mathbf{1 7} \mathbf{1 2 6 . 9 3}$ & $\mathbf{6 8 . 3 7}$ \\
\hline France & 5268.00 & 21.03 \\
Germany & 2973.02 & 11.86 \\
Netherlands & 2902.03 & 11.58 \\
Switzerland & 1953.49 & 7.79 \\
U.K. & 1790.10 & 7.14 \\
Italy & 1542.29 & 6.15 \\
Other European Countries & 698.00 & 2.78 \\
\hline USA & $\mathbf{3 0 0 4 . 3 7}$ & $\mathbf{1 1 . 9 9}$ \\
\hline Far Eastern Countries & $\mathbf{1 6 1 4 . 9 4}$ & $\mathbf{6 . 4 4}$ \\
\hline Japan & 1280.44 & 5.11 \\
South Korea & 206.00 & 0.82 \\
Singapore & 128.50 & 0.51 \\
\hline Middle East Countries & $\mathbf{6 6 9 . 7 7}$ & $\mathbf{2 . 6 7}$ \\
\hline Saudi Arabia & 289.27 & 1.15 \\
Bahrain & 165.00 & 0.65 \\
Iran & 108.00 & 0.43 \\
Other Middle Eastern & 107.50 & 0.43 \\
\hline Other Countries & $\mathbf{2 6 3 2 . 0 0}$ & $\mathbf{1 0 . 5 1}$ \\
\hline Total & $\mathbf{2 5 0 5 0 . 0 4}$ & $\mathbf{1 0 0 . 0}$ \\
\hline
\end{tabular}

Source: Undersecretariat of Treasury, General Directorate of Foreign Investment, Foreign Investment Report, September 1999.

Table 2. Foreign Trade Indicators 1980-2008 (\$ Billion)

\begin{tabular}{|lccccccc|}
\hline & $\mathbf{1 9 8 0}$ & $\mathbf{1 9 8 5}$ & $\mathbf{1 9 9 0}$ & $\mathbf{1 9 9 5}$ & $\mathbf{2 0 0 0}$ & $\mathbf{2 0 0 5}$ & $\mathbf{2 0 0 8}$ \\
\hline Exports & 2,910 & 7,958 & 12,959 & 21,636 & 27,774 & 73,5 & 105,4 \\
Imports & 7,909 & 11,343 & 22,302 & 35,707 & 54,502 & 116,8 & 163,5 \\
Deficit & $-4,999$ & $-3,385$ & $-9,342$ & $-14,071$ & $-26,728$ & $-42,3$ & $-58,2$ \\
\hline
\end{tabular}

Source: State Planning Organization of Turkey, Undersecretariat of Trade \& Treasury of Turkey.

Table 3. The results of ADF and PP unit root tests

\begin{tabular}{|ccccc|}
\hline & \multicolumn{2}{c|}{ ADF-test } & \multicolumn{2}{c|}{ PP-test } \\
\hline Variable & Level & First Difference & Level & First Difference \\
$F D I / G D P$ & $-2.575(3)$ & $-10.470^{\mathrm{a}}(1)$ & $-6.420^{\mathrm{a}}(5)$ & - \\
$E X / G D P$ & $-3.088(4)$ & $-3.958^{\mathrm{a}}(3)$ & $-4.940^{\mathrm{a}}(5)$ & - \\
$I M / G D P$ & $-2.999(4)$ & $-3.303^{\mathrm{b}}(3)$ & $-4.799^{\mathrm{a}}(2)$ & - \\
\hline
\end{tabular}

The numbers in parentheses indicate the number of lags in the augmented term of the ADF regression and are determined by using AIC information criteria. The number of truncation lags for PP test is chosen based on the Newey-West method. The unit root tests include a constant and time trend. ${ }^{\mathrm{a}, \mathrm{b}}$ represent the significance at $1 \%$ and $5 \%$ levels, respectively. 
Table 4. The results of the minimum LM unit root test based on Model CC

\begin{tabular}{|ccccccccc|}
\hline Series & $T B_{1}$ & $T B_{2}$ & $k$ & $S_{t-1}$ & $D_{1 t}$ & $D_{2 t}$ & $T_{1 t}$ & $T_{2 t}$ \\
\hline \multirow{2}{*}{$F D I / G D P$} & $2005: 01$ & \multirow{2}{*}{$2007: 01$} & 0 & $\begin{array}{c}-1.317 \\
(-10.845)^{\mathrm{a}}\end{array}$ & $\begin{array}{c}-0.006 \\
(-0.843)\end{array}$ & $\begin{array}{c}-0.051 \\
(-6.709)^{\mathrm{a}}\end{array}$ & $\begin{array}{c}0.005 \\
(1.964)^{\mathrm{b}}\end{array}$ & $\begin{array}{c}0.0004 \\
(0.087)\end{array}$ \\
\hline \multirow{2}{*}{$E X / G D P$} & \multirow{2}{*}{$1997: 03$} & \multirow{2}{*}{$2001: 02$} & 4 & $\begin{array}{c}-0.678 \\
(-5.600)^{\mathrm{c}}\end{array}$ & $\begin{array}{c}0.070 \\
(3.591)^{\mathrm{a}}\end{array}$ & $\begin{array}{c}-0.019 \\
(-1.108)\end{array}$ & $\begin{array}{c}-0.043 \\
(-4.501)^{\mathrm{a}}\end{array}$ & $\begin{array}{c}0.030 \\
(3.900)^{\mathrm{a}}\end{array}$ \\
\hline \multirow{2}{*}{$I M / G D P$} & \multirow{2}{*}{$1996: 02$} & \multirow{2}{*}{$1998: 03$} & 4 & $\begin{array}{c}-1.045 \\
(-6.437)^{\mathrm{a}}\end{array}$ & $\begin{array}{c}-0.107 \\
(-4.398)^{\mathrm{a}}\end{array}$ & $\begin{array}{c}-0.053 \\
(-2.710)^{\mathrm{a}}\end{array}$ & $\begin{array}{c}0.079 \\
(4.567)^{\mathrm{a}}\end{array}$ & $\begin{array}{c}-0.022 \\
(-2.428)^{\mathrm{b}}\end{array}$ \\
\hline
\end{tabular}

Critical Values of the Two Breaks Minimum LM Test

\begin{tabular}{|ccccccccccc|}
\hline$\lambda_{2}$ & \multicolumn{3}{c}{0.4} & \multicolumn{3}{c|}{0.6} & \multicolumn{3}{c|}{0.8} \\
\hline$\lambda_{1}$ & $1 \%$ & $5 \%$ & $10 \%$ & $1 \%$ & $5 \%$ & $10 \%$ & $1 \%$ & $5 \%$ & $10 \%$ \\
\hline 0.2 & -6.16 & -5.59 & -5.27 & -6.41 & -5.74 & -5.32 & -6.33 & -5.71 & -5.33 \\
& - & & - & & -6.45 & -5.67 & -5.31 & -6.42 & -5.65 & -5.32 \\
0.4 & - & & & - & - & - & - & -6.32 & -5.73 & -5.32 \\
\hline
\end{tabular}

$T B_{1}$ and $T B_{2}$ are the break dates, $\mathrm{k}$ is the lag length, $S_{t-1}$ is the coefficent on the unit root parameter. The figures in parantheses are t-statistics. Critical values for the coefficient on the dummy variables follow the standard normal distribution. ${ }^{\mathrm{a}, \mathrm{b}, \mathrm{c}}$ denote statistical significance at $1 \%, 5 \%$ and $10 \% . \lambda_{j}$ denotes the location of breaks. For Model CC, critical values depend on the location of the breaks and come from Lee and Strazicich (2003).

Table 5. Granger Causality test results

\begin{tabular}{|ccccc|}
\hline Null Hypothesis & Lag & F statistic & Probability & Decision \\
\hline FDI/GDP $-/ \rightarrow$ EX/GDP & \multirow{2}{*}{1} & 1.0313 & 0.2521 & Do not reject \\
\cline { 3 - 5 } & & 0.0313 & 0.8595 & Do not reject \\
\hline FDI/GDP $-/ \rightarrow$ FDI/GDP & \multirow{2}{*}{4} & 0.9469 & 0.9177 & Do not reject \\
\cline { 3 - 5 } IM/GDP $-/ \rightarrow$ FDI/GDP & & 2.9544 & 0.5655 & Do not reject \\
\hline
\end{tabular}

$-/ \rightarrow$ denotes "does not Granger cause". The test procedure is based on bivariate VAR(k) model.

Table 6. Dolado and Lüthkepohl Causality Test Results

\begin{tabular}{|cccc|}
\hline Null Hypothesis & MWALD Statistic & Probability & Decision \\
\hline FDI/GDP $-/ \rightarrow$ EX/GDP & 2.4205 & 0.6589 & Do not reject \\
\cline { 2 - 4 } EX/GDP $-/ \rightarrow$ FDI/GDP & 3.3033 & 0.5084 & Do not reject \\
\hline FDI/GDP $-/ \rightarrow$ IM/GDP & 0.5667 & 0.9667 & Do not reject \\
\cline { 3 - 4 } IM/GDP $-/ \rightarrow$ FDI/GDP & 2.3115 & 0.6787 & Do not reject \\
\hline
\end{tabular}

$-/ \rightarrow$ denotes "does not cause". The test procedure is based on bivariate $\operatorname{VAR}(\mathrm{k}+1)$ model. 